Вороніна М. С.

кандидат історичних наук, дочент, дочент кафедри всесвітньої історії Харківського начіонального педагогічного університету імені Г.С.Сковороди https://orcid.org/0000-0002-7533-7463

\title{
ЖІНОЧЕ СПОЖИВАННЯ В УСРР У 1920-1930-ТІ РОКИ: СТЕРЕОТИПИ ТА РЕАЛЬНІСТЬ
}

Для жіноитва в будь-які часи було важливо яскраво одягатися, бо до иього спонукали правила андроиентричного світу. Тому більш актуальними в даному дослідженні постають такі питання: по-перше, чи стала радянська жінка повноцінним споживачем; по-друге, чи змінювалася ії платоспроможність; по-третє, як відрізнялося споживання таких соиіальних страт, як городянки $i$ робітниці, селянки й колгоспниці, дружини командирів Червоної Армії, стахановки.

Ключові слова: жіноче споживання, рух «жен-общественниц», Стахановський рух, 1920-1930ті роки.

Consumption as a way of self-representation in Soviet society: between male, female and humor discourses. This panel explores consumption as a way of self-representation in Soviet society.International MAG Convention "The Image of the Self» Andrey Sheptytsky Center Ukrainian Catholic University Lviv, Ukraine June 27-29, 2018.

The main aim is to find the "faces» of consumers that could be seen through their consumption practices, spaces, commodities, and visual representations. The discussion (Daria Starikashkina, Nataliia Laas) aims at broadening our understanding of Soviet consumption as well as providing several insights into social, gender and, visual history. From the 1920-30s consumption was a valuable ideological and social tool of creating the imageof the new Soviet man (Iryna Skubii) and woman (Maryna Voronina). The real needs of ordinary male and female workers as well as "red directors» were far from idealistic view, created by ideology. It was said that socialism released a person from the power of things. However, from the early $1920 \mathrm{~s}$ Socialist ascetism was changed into industrial pragmatism. In the 1930s Stalin committed the "great retreat" in the ideology and formally declared the Soviet people's right to consume goods. But during the rule of Khrushchev a new slogan appeared: "Everything is for the sake of the people». Investigating satirical magazines as 'Perets' it is possible to find the "hidden face» of Soviet consumer (Katherina Yeremieieva). Thusat the article will discuss the following questions: How were the Soviet people portrayed: mainly as hard workers or consumers? How the self-representation of the ordinary male worker's consumer was transformed to those of the "red director»? Did the woman's solvency fluctuate to satisfy her everyday needs? What was the difference between the women consumption from the different social strata: urban and peasant women, female workers and collective farmers, wives of the Red Army commanders' and 'stakhanovka 's?

Keywords: Women's consumption, active wives' movement, "Soviet feminism», the Stakhanov movement, 1920-1930s.

Матеріали даної статті пройшли апробацію на International MAG Convention «The Image of the Self» Andrey Sheptytsky Center Ukrainian Catholic University Lviv, Ukraine June 27-29, 2018, де відбулася змістовна дискусія між Д. Старікашкіною, Н. Лаас, І. Скубій, К. Єремєєвою та М. Вороніною [1]. Головну суперечку спричинило питання: чи дискримінували радянських людей за споживання. Власне, позиція авторки відрізнялася від більшості, бо термін «споживання» надто умовний для 19201930-х років ХХ століття в СРСР, про що й піде далі мова.
Безперечно, роки національно-визвольних змагань, громадянської війни, іноземних інтервенцій не спонукали до розвитку фемінного споживання - воно стало маскулінним або гендерно-нейтральним (зброя, військовий одяг, продукти). Масовість такого явища як «мешочничество» свідчило про те, що село більш-менш забезпечувалося промисловими товарами, які вироблялись у суто російських губерніях або іноземними зі старих запасів, утім асортимент був надто непередбачуваний. Але чергові встановлення радянської влади призводили до антиспоживання: регулярні тижні «матері-пролетарки», «поранених чер- 
воноармійців» на офіційному рівні закликали жертвувати не лише гроші, а й речі широкого вжитку (постільне, одяг, портсигари, навіть носовички та ін.) [2, арк. 1-448]. Тому більше можна довіряти свідченням мемуарів сучасників про те, що це були «добровільно-примусові» пожертвування.

Таким чином, на момент уже остаточного встановлення функціонування радянської влади життя - як селянок, так і містянок - балансувало на межі споживання та натурального господарства. Як занотував полтавський лікар у своєму щоденнику за 15/2 травня 1920 року: «Жінки через нестачу взуття та страшенної дорожнечі шиють черевики на мотузяній підошві, замість капелюхів носять хустки, пов'язуючи ними голову. Чоловіки і жінки шиють одяг з простого кустарного грубого полотна і сукна. Чоловіки в більшості ходять у великих простих високих чоботях; мало на кому є старі калоші» [3, с. 156]. Неп, як вимушена стратегія, допоміг більшовикам втримати владу. Так, дійсно, почалося відновлення економіки, але на повсякденні пересічних жінок це слабо відображалося, навіть у представниць нової еліти були труднощі.

Окрім об'єктивних економічних ускладнень, траплялись і політичні. Якщо мислити в межах гендерних стереотипів, то регулярно відбувалося певне гендернокласове протистояння на кшталт: районний партійний комітет в «особі» відкритого зібрання комосередку 2-го Державного Заводу сільмашин (колишній «Мельгозе») 16.11.1922 р., після слухання докладу про діяльність Міської Ради робить членам ії наступний наказ: «6) Покласти край розпусті, а також випічці всіляких тістечок та інших делікатесів і заборонити помел білого борошна» [4, арк. 22]. Але від економічної теорії важко сховатися: «Споживання це процес задоволення потреб матеріальними і духовними благами». Подібні постанови просто відносились саме до останнього, бо до сьогодні виносяться в публічний простір, утім їх частка серед інших дискусій, судячи 3 масиву джерел, більш ніж скромна.

Більш важливо розібратись із гендерним складом країни. Дослідниця С. В. Маркова стверджує: «У 1924 р. було зафіксо- вано зниження смертності жінок на фоні зростання смертності чоловіків, а також найвищу кількість сільських удовиць у Європі (в усіх вікових групах населення жінок-удів було значно більше, ніж чоловіків, приблизно в сім разів, це свідчить не лише про суттєве зростання смертності серед дорослих чоловіків, але й також про те, що жінкам-удовицям на селі було досить важко вийти заміж)» [5, с. 15]. Головне - пам'ятати, що коли мова йде про «сільське населення», то це майже $80 \%$ населення УСРР у довоєнний період. Для них навіть «8 березня» переносили: у Старобільську [сучасна Луганщина] в 1925 році ««Тиждень матері пролетарки» в місті пройде 38 березня, а на селі - 310 квітня, коли селяни будуть більш вільними». Також жінвідділ прагнув забезпечувати й інші духовні блага, постійно долаючи гендерні перепони: «Лікнеп відвідують лише $5 \%$ делегаток, тому що в одні й ті самі ж школи влиті й допризовники, й [заміжні] жінки чоловіки в школу не пускають... думають відкрити окремі» [6, арк. 2]. Намагалися подолати, бо працівниці жінвідділів та різного штибу жінорганізатори не «відірвалися від народу». 1925 рік Маріупольський Округ: жінорганізатори по 2-3 місяці не мали засобів пересування для виїзду на село - не було чобіт [7, арк. 21]. Чи дійсно саме це було причиною зволікання 3 роботою серед жіноцтва, об'єктивно дізнатися важко. Утім, по-перше, це офіційний звіт для партійних функціонерів, по-друге, на початку 1920-х подібні фрази можна зустріти у звітах з усіх українських регіонів у холодну пору року, бо влітку вони ходили по селах босоніж.

Час непу збігав, і контроль держави над споживанням беззаперечно мав перемогти, але, маючи всі привілеї, а проте в цій боротьбі не було переможців, а лише переможені, і насамперед саме споживачі. У квітні 1928 року на засіданнях столичного Жіночого відділу були озвучені такі проблеми: «Крім того, спостерігаємо моменти, коли приватник вдавався до примусового асортименту: хочеш купити хліба, купуй оселедець та інше... але в державних ще гірше обслуговують, антисанітарія, обвіс». «Хлібний ринок, що перебуває в руках 
ХЦРК, в питанні про зниження цін, на превеликий жаль, рівняється за приватником» [8, арк. 48-49]. Проголошення курсу на індустріалізацію остаточно закріпило абсолютний авторитет важкої промисловості. Більш правдиво, що це був курс на мілітаризацію, тож розвиток легкої промисловості був відповідним, утім останне не афішувалось. Тому, наприклад, на святковому засіданні 8 березня 1929 року делегатка від Москви Черенкова 3 надривом проголосила: «Московська [партійна] організація нещодавню пережила важке становище, коли окремі керівники... пропонували розвивати в першу чергу легку індустрію, це, товариші, шлях до загибелі пролетаріату» [9, арк. 40].

Далі все більше набирав обертів так званий «Великий стрибок». Тоталітарна держава щодалі більше починала сама формувати «правильне» жіноче споживання, так би мовити, не міщанське і буржуйське. Напередодні 8 березня 1931 року Бородянський КНС (Київщина) постановив: «Зібрати кошти на збудування ескадрильї і зокрема літака "Незаможниця країни" i "Незаможник України"» [10, арк. 22]. А напередодні Й. В. Сталін звітував щодо світової кризи: «Теперішня економічна криза $€$ криза надвиробництва... Це значить, що вироблено мануфактури, палива, фабричнозаводських виробів, предметів харчування більше, ніж можуть купити за готівкові гроші основні споживачі, тобто народні маси, доходи яких залишаються на низькому рівні» [11]. Утім, наслідки цієї «капіталістичної» кризи не оминули країну Рад: інфляція, колосальна додаткова емісія, яка ще більше підштовхнула інфляцію [12]. Тільки 31 січня 1935 року поступово почали відміняти карткову систему, яка була введена з 1929 року на хліб, а потім і на решту продовольчих та промислових товарів.

Будь-яка держава за таких умов не здатна відповідно збільшувати заробітну плату, а СРСР і поготів не міг бути винятком. Тому звичайне ударництво для пересічних робітниць не мало сенсу, їм краще було витрати свої сили на присадибну ділянку, рукоділля, заміжжя й аборти, бо іншого шляху не збільшувати утриманців не було. Але навіть таке становище робіт- ниць однаково було кращим за долю колгоспниці, яка не належала навіть до категорії утриманців, адже на селі була абсолютна гендерна рівність: чоловіки-колгоспники також, окрім зарахованих трудоднів, нічого не отримували. Навіть комерційні магазини географічно не були на відстані досяжності для тих же ударників. Приміром, у с. Кіндрашівка Куп'янського повіту на Харківщині за 1 трудодень у 1932/33 році виплачували по 300 г зерна та 15 коп. грошима [13, c. 702], тобто навіть якби зарахувався трудодень за кожний день у році, чого не було, то це нижче за рівень виживання для дорослої людини, не кажучи про наявність у неї дітей... Тому й не дивно, що другим пунктом у промові на I Всесоюзному з'їзді колгоспників-ударників Й. Сталін проголосив: «Наше найближче завдання - зробити всіх колгоспників заможними». У тексті промови, звісно, тотальна підміна понять: «Проте 20 мільйонів бідняків - врятували від злиднів і розорення, врятували від куркульської кабали i перетворили завдяки колгоспам у забезпечених людей» [14]. Але ж у надрукованому вигляді більшість запам'ятає сім слів жирним шрифтом, а не десятки рядків алогічного дрібного тексту.

Та життя тривало, дедалі більш поширеною ставала така послуга, як дитячі садки. I саме тоді була запроваджена така пільга (в м. Харків вона існує і сьогодні, єдине, що за радянської влади, на відміну від сучасної ринкової економіки, вона була диференційована): «Плата за дитину від 50 до 80 крб./місяць, а собівартість 100 крб./місяць, дотацію надає Міськрада» [15, арк. 22]. Для порівняння: у розпал руху багатоверстатниць у серпні 1937 року у славнозвісних Вічугах Іванівської області сама Дуся Виноградова з обкладинки журналу «Тіте» жалілася, що на фабриці почались негаразди після іiї від’їзду до промакадемії: «Деякі ткалі, що заробляли по 280-300 карбованців, тепер заробляють 180. Ткалі на 216 верстатах заробляли по 1200-1300 крб., тепер 900... Робітницям доводиться їздити за продуктами до Іваново (60 км) або в Кінешму (22 км)» [16]. Останні, звісно, не $\epsilon$ пересічним випадком, а от перші презентували той рівень, до якого прагнули робітниці легкої промисловості всього СРСР - 
тільки ж сільськогосподарське виробництво не встигало за споживанням.

«Так, у 1933 р. за один робочий день колгоспниця виробляла 0,87 трудодня, 1934 р. - 0,95 трудодня і в 1935 р. - 0,99 трудодня», і в той же час жінка - голова артілі за 1935 рік виробляла 442 трудодня, навіть офіційна статистика визнавала: «У загальному фонді трудоднів, що виробляла вся родина колгоспника, на долю жінок припадало від 23 до $46 \%$ \% [17, с. 40, 42]. Нарахування трудоднів трактористам - 4,5 на колесних і 5 трудоднів на гусеничних, а 3 отриманням кожної категорії оплата збільшувалася від 10\%, за перевиконання норми - прогресивне збільшення. Приміром, більше $50 \%$ - у подвійному розмірі, бригадиру також бонуси. Тобто економічні закони брали своє: «Саме споживання породжує мотивацію до праці» і лозунг «100 тисяч подруг на трактор!» П.Ангеліної не лише через пропаганду зреалізувався. Тому й фемінні, й маскулінні приклади трудового героїзму стикалися з банальною матеріальною зацікавленістю. Тож на II Всесоюзному з'їзді колгоспників-ударників 11-17 лютого 1935 року було вирішено проводити Всесоюзні сільськогосподарські виставки, диплом першого ступеня - премія по 10000 крб. і автомобіль, другого ступеня по 5000 крб. і мотоцикл тощо [18, с. 4].

Утім, більшовицьке керівництво не втрачало надію на домінування політики у вигляді зрівнялівки. Як би не проголошувались заклики до ідеалу «Нової жінки», навіть на середину 1930-х років «контракт працюючої матері» ще не став пересічним. Надто велика кількість жіноцтва належала до такої радянської гендерної страти, як «дружини»: «робітників», «стахановців», «командирів виробництва», «командирів Червоної Армії». Перші дві категорії усе ж таки залишались в ідеологічно привілейованому становищі класу-гегемона. А от останні дві вирішили використати як безкоштовний ресурс у реалізації заклику до «нового побуту». Більшість дружин командирів Червоної Армії були непрацюючими, але й загальний рівень освіченості був не надто високий, бо нова військова еліта була переважно все ж таки 3 робітничо-селянських страт. У 1924 році в армії не було на- віть нового обмундирування, в усіх округах не вистачало білизни: «в Одесі жилтовариства та крамниці обкладалися податком на допомогу казармі» [19] - тобто привілеєм пересічного офіцера та його дружини були обмундирування й білизна...

А от дружини керівників виробництва, судячи з їхніх спогадів, не надто помітили перехід від капіталізму через війни до соціалізму. Абсолютна більшість мали за плечима або гімназію, або інститут шляхетних дівчат, а то й вищу освіту, не працювали й мали хатніх робітниць. «Я казала чоловікові, що треба повертатися в Москву. Тут мені не подобається. Коли потрібно було замовити нове пальто, я повинна була поїхати до Дніпропетровська. Тут є кравці, але немає хороших кравчинь. Важко купити що-небудь і для себе і для дитини, i нудно... У нових промислових селищах організовані кравецькі майстерні, що виконують замовлення на індивідуальну пошивку пальто, піджаків, брюк і т.д. Але майже ні в одній пошивній майстерні ви не знайдете жіночого відділення, в якому дружина фахівця могла б замовити собі за дешевою ціною гарне пальто, кофточку та ін.» [20, c. 13]. От саме до них дійшла черга в серці маскулінної індустріалізації - тодішній Дніпропетровщині. Спочатку на громадських засадах вони покращували харчування в заводських їдальнях: обід (Запоріжжя, 1936 рік) за кращими цінами - 3,2 крб (борщ, печеня, відбивна, компот), м'ясо для їдальні - 6 крб/кг замість 12 крб/кг. Відтак, щоб забезпечити гуртожитки та дитячі садочки, їздили за подушками, ковдрами, постільною білизною до Харкова, жалілись, що гуртової торгівлі немає. Добивалися, щоб слюсар із родиною із землянки переїхав до іншого житла, і просто роздавали рекомендації робітницям щодо засобів гігієни та розповідали, де продається рідина для полоскання рота, щітка і порошок [21, c. $47,70,56]$. Врешті решт більшість із них працевлаштувалися на керівні посади в їдальнях, гуртожитках, дошкільних та позашкільних закладах освіти, клубах і т.д., щоб не займатися міщанським жіночим споживанням.

Висновки. Таким чином, ми бачимо, що бажання добре їсти й одягатися в старо- 
режимних традиціях більшовики викоренити не змогли, а тільки довести до всепоглинаючого зубожіння все населення СРСР та УСРР. Винятком ставали тільки представники нової еліти і старі інженерно-технічні кадри. Головним трендом усієї радянської епохи став дефіцит як продовольчих, так промислових товарів, і в цьому плані більшовики досягли певної гендерної рівності у своєму постійному обмеженому споживанHi.

\section{ЛІТЕРАТУРА}

1. International MAG Convention «The Image of the Self» Andrey Sheptytsky Center Ukrainian Catholic University Lviv, Ukraine June 27-29, 2018. https://s3-eu-central-1.amazonaws.com/ucu. edu.ua/wp-content/uploads/sites/32/2017/ 11/Program-Book_Final.pdf

2. Державний архів Донеиької області Ф. Р-2, оп. 1, спр. 27, арк. 1-448.

3. Несвицкий А.А. Полтава в дни револющуии и в период смуты 1917-1922 г2.: Дневник. Полтава, 1995. С. 156. Сайт Тристанова. История Полтавы. Режим доступу: http://histpol.pl.ua/ru/poltava-istoricheskieocherki/istoricheskie-ocherki? id $=482$

4. Державний архів Харківської області. Ф Р-408, оп. 2, спр. 56, арк. 1-103.

5. Маркова С.В. Суспільно-політичні зміни в українському селі у контексті формування комуністичної системи (1917-1933 рр.): автореф... дис. д-ра іст.наук. Чернівиі, 2016. 38 с.

6. Державний архів Харківської області Ф. 11, оn. 1, спр. 102, арк. 1-98.

7. Державний архів Харківської області Ф. 11, оn. 1, спр. 102, арк. 1-98.

8. Державний архів Харківської областіФ Р-408, оп. 4, спр. 120, арк.1-70.

9. Державний архів Харківської області Ф Р-408, оп. 4, спр. 128, арк. 1-50.

10. Державний архів Харківської області Ф. 1084, оп. 1, спр. 10, арк.1-94.

11. Политический отчет Центрального Комитета ХVI съезду ВКП(б) 27 июня 1930 г. И.В. Сталин.
Режим доступy: https://www.marxists.org/russkij/ stalin/t12/t12 21.htm

12. Дэвис Р. У., Хлевнюк О. В. Отмена карточной системы в СССР 1934-1935 годы. Режим досmyny: $w w w . f e d y$-diary.ru/?page_id $=5756$

13. Історія міст і сіл Украӥнської РСР. Харківська область. К: Головна редакиія УРЕ АН УРСР, 1966. $1086 \mathrm{c}$.

14. Сталин И. В. Речь на Первом Всесоюзном съезде колхозников-ударников 19 февраля 1933 годаРежим достуny: http://www.marxists.org/russkij/ stalin/t13/t13_39.htm

15. Державний архів Харківської області. Ф. Р-408, оn. 10, спр. 119, арк. 1-35.

16. Виноградова Е. Письмо из Вичуги // Правда № 211(7177), 2 августа 1937.

17. Женщина в СССР (Статистический сборник) ЦУНХУ ГОСПЛАНА СССР и СОЮЗОРГУЧЕТ, Москва, 1937. 184 c.

18. Главный комитет всесоюзной сельскохозяйственной выставки // Социалистическое земледелие. 4 апреля 1941. № 41(3549). С. 4. [Электронный ресурс] «Старые газеты» - память пройденных дорог... Режим доступу: www.oldgazette.ru/ssemle/04041941/index1.html

19. «Совершенно Секретно»: Лубянка Сталину о положении в стране (1922-1934 г2.), m. 2, 1924, ч. 1, 2. Москва, 2001. Режим доступу: http://istmat.info/node/24611

20. Жена инженера. Авторский коллектив жен ИТР «Запорожстали». М.; Л., 1936.90 с.

21. Там само.

\section{REFERENCES}

1. International MAG Convention "The Image of the Self" Andrey Sheptytsky Center Ukrainian Catholic University Lviv, Ukraine June 27-29, 2018. Retrieved from: https://s3-eu-central-1.amazonaws. com/ucu.edu.ua/wp-content/uploads/sites/32/2017/ 11/Program-Book Final.pdf

2. State Archives of Donetsk Region F. R - 2, op. 1, sp. 27, ark. 1-448. [in Ukrainian].

3. Nesvitsky A.A. (1995) Poltava in the days of the revolution and in the period of distemper 19171922:Diary. - Poltava, 1995. - 280 p. P. 156. Site Tristanova. Poltava history: - Retrieved from: http://histpol.pl.ua/ru/poltava-istoricheskieocherki/istoricheskie-ocherki? id=482 [in Russian].

4. State Archives of Kharkiv Oblast F-408, op. 2, pp. 56, ark. 1-103, ark. 22 [in Ukrainian].

5. Markova, S.V.(2016) Social-political changes in the Ukrainian village in the context of the formation of the communist system (1917-1933). Extended abstract of Doctor's thesis. Chernivtsi [in Ukrainian].

6. State Archives of Donetsk Region F. 11. op. 1, sp. 102, ark. 1-98, ark. 2 [in Ukrainian].

7. State Archives of Donetsk Region F. 11. op. 1, sp. 102, ark. 1-98, ark. 21 [in Ukrainian].

8. State Archives of Kharkiv Oblast $\Phi-P-408$, op. 4, pp. 120, arc .. 1-70, ark. 48-49. [in Ukrainian].

9. State Archives of Kharkiv Oblast $\Phi-P-408$, op. 4, pp. 128, arch .. 1-50, ark. 40. [in Ukrainian].

10. State Archives of the Kyiv region, 1084, op. 1, sp. 10, arc. 1-94, ark. 22. [in Ukrainian].

11. Political Report of the Central Committee to the XVI Congress of the CPSU (b) June 27, 1930 I.V. Stalin. - Retrieved from: https://www.marxists.org/russkij /stalin/t12/t12_21.htm [in Russian].

12. Davis, P.U., Khlevnyuk, OV Cancellation of the rationing system in the USSR 1934-1935. - Retrieved from: $w w w$.fedy-diary.ru/?page_id=5756 [in Russian]. 
13. History of cities and villages of the Ukrainian SSR. Kharkiv region. - K: Editorial board URE Academy of Sciences of the USSR, 1966. - 1086 p. 702. [in Ukrainian].

14. Stalin. I.V. 1933 Speech at the First All-Union Congress of Collective Farmers-Drummers on February 19, 1933 - Retrieved from: http://www.marxists.org /russkij/stalin/t13/t13_39.htm [in Russian].

15. State Archives of Kharkiv Oblast Ф. P-408, on.10, cnp. 119, ark. 1-35, ark. 22. [in Ukraine].

16. Woman in the USSR (Statistical collection) TSUNHU GOSPLAN of the USSR and V/O SOYUZORGUCHET, Moscow, 1937-184 p. Pp. 40, 42.

17. The main committee of the All-Union Agricultural
Exhibition. // Socialist agriculture. - April 4, 1941. No. 41 (3549) S. 4. The website "Old newspapers" a memory of the roads covered... Retrieved from: www.oldgazette.ru/ssemle/04041941/index1.html [in Russian].

18. «Top Secret»: Lubyanka to Stalin on the situation in the country (1922-1934), vol. 2 1924, part 1, 2, Moscow, 2001. - Retrieved from: http://istmat.info/node/24611 [in Russian].

19. Engineer's wife. The authors 'team of the Zaporozhstal engineers' wives: M.L. 1936. 90 p. P.13 [in Russian].

20. Ibid 47, 70, 56[in Russian]. 